DOI: $10.30525 / 978-9934-588-61-7-32$

Irtysheva I. O.

Doctor of Economic Sciences, Professor,

Head of the Department of Management

Admiral Makarov National University of Shipbuilding

Tubaltseva N. P.

Candidate of Economic Sciences, Associate Professor, Senior Lecturer at the Department of Economics and Manufacturing Management Admiral Makarov National University of Shipbuilding

Tubaltsev A. M.

Associate Professor at the Department of Ecology and Environmental Technologies

Admiral Makarov National University of Shipbuilding

\title{
CREATIVE MANAGEMENT AS A FOUNDATION FOR EFFECTIVE DEVELOPMENT OF THE TOURIST INDUSTRY
}

\section{Summary}

It is determined that tourism is a sector of the creative economy. The relevance of the use of creative management approaches in the tourism industry is proved. It is justified that the services of the tourism sector cease to be standard and acquire new features. The ratio of traditional and modern types of tourism is given. It is shown that Ukraine has all the prerequisites for intensive development of the tourism industry. Systematic proposals for the use of the country's tourism potential based on the introduction of components of creative management are provided.

\section{Introduction}

Tourism has become a driving force of socio-economic development in many countries. In more than 100 countries, tourism contributes to a high level of employment, development of individual regions and is an important item of revenue to the state budget; it generates more than $10 \%$ of revenue, or 8.8 trillion USD, in the global economy. According to the UN World Tourism Organization, the tourist contribution to the world economy is estimated at $10 \%$ of world gross domestic product. International tourism (travel and passenger transportation) accounts for $30 \%$ of world exports of services and $7 \%$ of total exports of goods and services. Tourism provides jobs for every eleventh person in the world.

Ukraine's economy, which is aimed at active integration into the world economy, the tourism industry, despite becoming an increasingly important determinant of socio-economic development, still leaves the country at the lowest ranking positions in the world tourism market. There are many reasons 
that hinder the development of this activity. However, the use of creative management will assist in changing the situation and boost the development of the tourism industry in Ukraine with the help of non-standard creative approaches in the conditions of limited financial resources. Improvement of the mechanisms of tourism industry is especially relevant today, because tourism is a catalyst for the economy and contributes to the development of construction, trade, and employment. A significant contribution to the study of tourism problems is made by domestic and foreign scientists A.V. Zymovets, I.V. Zorin, M.P. Malskyi, N.V. Antoniuk, N.M. Hanich, D.N. Borovynska, V.V. Lapochkina, N.V. Novychkov, V.Yu. Yakovlev and others. The works of Yu.O. Nikolaiev, I.I Sokoly, N.S. Andrusiak, M.V. Bahrii, I.O. Irtyshcheva are devoted to the research of tourist clusters. The aim of the article is to determine the essence, significance and features of creative management approaches for the effective development of the tourism industry.

\section{Part 1. Creative management: nature, significance and features of development of tourism industry}

Endorsement of the concept of post-industrial society (coined by D. Bell in 1973 ) is the intensification of the transition from the production of goods to the predominance of service industries. As a result of this process, shift in the value system is observed, which is the result of the reflection of modern economic and social phenomena. In the context of fierce competition, creativity is emphasized. It is a specific and controversial characteristic that affects the development of business, economy and management. In a broad sense, creativity characterizes a non-trivial solution to a problem in a nonspecialized way, often limited by means and resources [2]. Today, the whole world uses terms such as creative thinking, creative economy, creative industry, creative product, and creative management.

Creative thinking is a mental activity that reflects individual's creative abilities and contributes to the production of the fundamentally new ideas or processes. According to professor I. Myloslavskyi, the term «creative» refers to creativity that does not only put forward ideas, but also brings them to a specific practical result.

Today, creative economy is a profitable business. The Creative Trade Report of the United Nations Conference on Trade and Development (UNCTAD) (2008) proposes a broader definition of the creative economy: «The link between creativity, culture, economics, and technology, which finds its expression, above all, in the ability to create and launch intellectual capital with the potential to generate income, create new jobs and ensure export earnings, as well as promote social integration, cultural diversity and human development» [3]. The concept of «creative economy» was introduced by BusinessWeek magazine in August, 2000. In Europe, it includes 13 sectors of the economy [3].

The term of creative industry first appeared in Great Britain in the 90s of the 20th century, where the definition of creative industries was first formulated; it is considered canonical today. Creative industries were defined 
as industries that «take their origin in individual creativity, skill and talent, with the potential to create added value and create new jobs through the generation and exploitation of their intellectual property». The analysis of the discourse of «creative industries» shows that this term is not so much a theoretical concept as a political and economic program. It implies that the use of creative approaches will help to create conditions for a competitive economy, integrated into the global system of division of labor, the emergence of new jobs and the solution of social problems in the region [2].

Tourism is considered to be a sector of the creative economy, which is often called the experience economy. The term «experience economy» was proposed in the book by B. Joseph Pine II and James Gilmore, "The Experience Economy. Work is Theater, and Every Business a Stage» (2005), and its appearance was predicted back in 1970 by Alvin Toffler [3]. The experience economy is an approach to the production and promotion of a product or service that is not based on meeting a specific need, and to creation of a positive impression of both production and promotion, and of receiving a product or service [3]. Experience economy is not the industry of producing impressions, it is a paradigm shift in a buyer-seller relationship. The emergence of experience economics is associated with a change in the nature of human needs. The development of communications and general informatization leads to disunity, therefore, a person seeks to have an unforgettable experience.

According to gerontologists, new experiences are just as necessary for the central nervous system, for its full-fledged work, as well as the satisfaction of the need for sleep, and the monotony of life, boredom and the absence of new experiences lead to premature aging. Interest in everything new and unknown is the strongest anti-aging factor. The need for new emotions and feelings arises from the need for a sense of life and social communication. Emotional positive outbursts are stored for a long time in memory, in contrast to the acquired new purchases. It is no coincidence that today 12 million people visit Disneyland Paris versus 6 million people visit the Louvre [4].

The modern consumers, who are able to satisfy their cognitive needs via the Internet, are waiting for new unusual routes from the tourism industry, hoping to get a new experience. Marketers, engaged in the promotion of services, are mastering new tools that affect not the consumers' mind, but their feelings, trying to strike the right note, to rely on pleasant emotions [4].

Tourism as an industry for the production of impressions is at the forefront of the creative economy, where there is a tendency that the share of value added is increasing in the chain «raw materials - goods - services impressions». Tourism industry products are no longer standard, tourism organizations are developing new routes and individual service programs, taking into account non-standard desires. Traditional types of tourism are beginning to take on new features (Table 1); in route and stationary tourism, objects that meet the requirement of exoticism come to the fore. 
Traditional and modern types of tourism

\begin{tabular}{|c|c|c|}
\hline Traditional types of & Modern realization & Experience \\
\hline \multirow[t]{6}{*}{ Cognitive excursion } & Man-made & $\begin{array}{l}\text { Mining (visiting a mine, a } \\
\text { quarry) }\end{array}$ \\
\hline & Adventure & $\begin{array}{l}\text { Getting new experience in } \\
\text { an extreme situation }\end{array}$ \\
\hline & Gastronomic & $\begin{array}{l}\text { Tasting national dishes, } \\
\text { acquaintance with the } \\
\text { technologies of winemaking, } \\
\text { cheese making, brewing }\end{array}$ \\
\hline & Religious & $\begin{array}{l}\text { Acquaintance with temples } \\
\text { and monasteries, the life of } \\
\text { monks. }\end{array}$ \\
\hline & $\begin{array}{l}\text { Creative (visiting pottery and } \\
\text { art workshops) }\end{array}$ & $\begin{array}{l}\text { Combining outdoor } \\
\text { activities with self- } \\
\text { realization and creativity }\end{array}$ \\
\hline & $\begin{array}{l}\text { Hobbies: } \\
\text { - visit to existing and closed } \\
\text { industrial enterprises; } \\
\text { - visiting both collapsed and } \\
\text { existing military facilities, } \\
\text { - visiting places of } \\
\text { deprivation of liberty; } \\
\text { - visiting mythical places }\end{array}$ & $\begin{array}{l}\text { Getting insights on industrial } \\
\text { technology, military insta- } \\
\text { llations, prisons and camps; } \\
\text { Solitary confinement in a } \\
\text { punishment cell and acquain- } \\
\text { tance with prison food; } \\
\text { Acquaintance with legends, } \\
\text { tales, myths }\end{array}$ \\
\hline Event & $\begin{array}{l}\text { Exotic: } \\
\text { - natural phenomena; } \\
\text { - marriage ceremonies; } \\
\text { - acquaintance with the } \\
\text { northern nature and the } \\
\text { icebreaker }\end{array}$ & $\begin{array}{l}\text { Eclipse, volcanic eruption, } \\
\text { etc.) } \\
\text { on the ice of Lake Baikal, } \\
\text { under water or during a } \\
\text { parachute jump } \\
\text { Icebreaker cruise along the } \\
\text { Northern Sea Route. }\end{array}$ \\
\hline Active & Extreme & $\begin{array}{l}\text { Expeditions in the footsteps } \\
\text { of ancestors, participation in } \\
\text { the search for ancient plants, } \\
\text { rejection of the modern } \\
\text { achievements of civilization; } \\
\text { Extreme environmental } \\
\text { conditions; } \\
\text { Non-standard methods of } \\
\text { movement; } \\
\text { Travel associated with a risk } \\
\text { to life. }\end{array}$ \\
\hline
\end{tabular}


(End of Table 1)

\begin{tabular}{|c|c|c|}
\hline $\begin{array}{c}\text { Traditional types of } \\
\text { tourism }\end{array}$ & Modern realization & Experience \\
\hline Health improving & $\begin{array}{l}\text { Sanatorium and resort health } \\
\text { improvement } \\
\text { Beauty tours }\end{array}$ & $\begin{array}{l}\text { The use of medicinal waters, } \\
\text { the sea coast, } \\
\text { The use of alternative } \\
\text { medicine (apitherapy, } \\
\text { hirudotherapy, acupuncture, } \\
\text { iridodiagnosis, } \\
\text { hippotherapy, etc.). } \\
\text { SPA tours - anti-aging } \\
\text { wellness programs; } \\
\text { Anti-stress programs } \\
\text { Complexes of } \\
\text { «meteorological } \\
\text { dependence», } \\
\text { Weekend spa programs, } \\
\text { Programs of «men's health» } \\
\text { and «women's health», } \\
\text { «Healthy breathing» and } \\
\text { «healthy sleep»; } \\
\text { The use of alternative } \\
\text { medicine (apitherapy, } \\
\text { hirudotherapy, acupuncture, } \\
\text { iridodiagnosis, } \\
\text { hippotherapy, etc.). }\end{array}$ \\
\hline Agritourism & $\begin{array}{l}\text { Commercial gathering of } \\
\text { mushrooms, berries, nuts, } \\
\text { flowers, medicinal plants, } \\
\text { sea mollusks, corals, } \\
\text { precious and semiprecious } \\
\text { stones and minerals, other } \\
\text { gifts of nature, collecting } \\
\text { butterflies, beetles, drawing } \\
\text { up a herbarium, etc. }\end{array}$ & \\
\hline Ethnographic & $\begin{array}{l}\text { Jailoo tourism is a tribal } \\
\text { residence, in which a } \\
\text { primitive system has been } \\
\text { preserved without any } \\
\text { benefits of civilization or } \\
\text { away from habitable places } \\
\text { among natives living in } \\
\text { subsistence farming }\end{array}$ & $\begin{array}{l}\text { New impressions, feelings } \\
\text { when giving up the benefits } \\
\text { of civilization }\end{array}$ \\
\hline
\end{tabular}

The process of creating impressions must be controlled. Creative management and innovative thinking professionals can provide this process. Creative management is a type of management carried out for profit through the organization and promotion of creative activity, it is a synergy of two energies: creativity and business, the implementation of the activities of the artist and entrepreneur. Creative management implies: considering the problem from all sides, making full use of the creative thinking of employees, 
finding a non-standard solution to the problem based on the most complete information, the ability to link technological processes of various activities in a rapidly changing environment.

The system of creative management of the tourism industry has also specific features in addition to general. The specificity is that managers need to respond to emerging events, which cannot be predicted, quickly and clearly. In creative management, it is necessary to respond to unexpected situations quickly, this requires managers with operational thinking, which is based on: a quick analysis of the situation, vision of the consequences and finding a specific decision algorithm. The feature of managing the activities of travel companies is that it is necessary to coordinate and integrate the functioning of various business entities (hotels, transport organizations, cafes and restaurants, information centers) into a single tourist route.

The creative management strategy is based on the entrepreneurial spirit of both the leader and the entire team. The creative potential of a tourism organization depends on the variety of intellects, education, psychology and methods of thinking of each employee, which together increase the synergistic effect. Management efficiency is determined by both cohesive collective activity and the methods of thinking of each company employee, which allows to design a creative product (non-standard route or excursion). It is advisable to select managers who are different in their creative properties in a travel agency. The pre-existing five types of thinking (synthesist, analyst, idealist, pragmatist, realist) are now supplemented with role-based functions:

- pioneer (problematic) who sees and formulates a problem earlier than others.

- encyclopedist who quickly finds analogues of the problem under consideration in other areas of knowledge, finds the necessary information and protects from the stereotype, which contributes to the use of new methods of solving problems. The encyclopedists most accurately anticipate the consequences, more subtly sense trends. They calculate all outcome options and make the risk assessment.

- generator of ideas is the person who analyses and synthesizes many ideas for a specific purpose. It is a specialist who develops a concept that brings together many ideas.

- enthusiast is a specialist who embraces others with optimism and confidence in the success of solving a problem, achieving a result.

- skeptic is an employee who acts as a «brake» of the task, doubts its success, formulates pitfalls, warns against making ill-conceived decisions.

- aesthete is a supporter of good ideas and elegant solutions. He or she claims that «a concept or solution can only be right when it is beautiful». Practice shows that the concept of beauty is not so far from science, for a good idea, thought is associated with the beauty and aesthetics of perception.

- psychologist is a specialist who creates a certain psychological atmosphere in a team. It is not only an atmosphere of mutual understanding and cooperation, but also an atmosphere of enthusiasm. 
- the independent manager is a type of specialist who likes to work individually and autonomously. He or she studies other people's ideas, but finds his or her own, which makes a significant contribution to the overall result of the team.

- translator is a specialist who intelligibly explains the problem, the process of solving it to specialists in other areas of knowledge. This manager has good qualifications, experience, and level of thinking.

- developer knows how to bring research results to practical, real results. He or she knows how to select essential and non-essential components and effectively translates ideas and concepts into reality. The developers note that people with a strict distribution of distinguished types do not exist. Each specialist can have a combination of certain properties belonging to several types [6].

So, creative management in the tourism sector helps to stimulate creative activity in generating, searching, choosing new routes, tours, excursions to meet consumers' needs and obtain high economic and social results.

\section{Part 2. Creative management in tourism industry: features of development and implementation in Ukraine}

Tourism has a positive impact on the development of other sectors of the economy, including hospitality, transportation and communications, construction, retail, souvenir production and trade, as well as it is a catalyst for their development. In addition, this activity is aimed at meeting people's needs in learning about the history, culture, customs, spiritual and religious values of different countries and their peoples.

Reasonably, our country has all the prerequisites for intensive development of domestic and foreign tourism: features of geographical location and topography, favorable climate, rich natural, historical, cultural and tourist recreational potential. In particular, it is one of Europe's leading countries in terms of historical and cultural heritage. There are 150000 immovable monuments of history and culture alone, including 57206 archeological monuments, 51364 historical monuments, 16800 landmarks of architecture and urban planning, about 200 castles, only 50-60 of which are relatively well maintained. Six unique natural healing resources have been recognized as resorts of national importance: Sloviansk, Khmelnytskyi, Myrhorod, Berdiansk, Skadovsk, Truskavets. Two well-known national clusters can be distinguished as:

1) rural («green») tourism - «EKOTUR», «Kamianets», «Picturesque Berezhanshchyna», «Dnipro-cross-border», «Oberih», in six adjacent border areas of Homel and Chernihiv regions;

2) cognitive tourism, represented by the inter-regional cluster «Southern Tourist Ring», which covers the territory of Odesa, Mykolaiv, Kherson regions (here entered the Voznesensk tourist cluster) [7].

It is very important for managers working in the tourism industry to understand the macroeconomic trends and basic aspects of their region's development, to analyze the current market, to weigh supply and demand for 
tourism services, to see ways to solve numerous problems, to find ways to enhance advertising in their region as a tourist. The introduction of creative management components will help to increase the efficiency of the tourism sphere. In our view, there are several points to consider. Firstly, when designing excursion tours, the mindset of the tourist service consumers is taken into account. Indeed, shopping tourism is becoming popular in Ukraine. In this case, the relative cheapness or uniqueness of the product is a motivating factor. Photo tours and religious tourism are also in demand.

Secondly, the prolonged dominance of domestic tourism in the socialist era caused a surge in demand for international travel, reflecting the change in status and expansion of Ukraine's participation in the international tourism market, where it has transformed from a recipient country into a tourist flow generator. The trend of outbound flow over inbound in the structure of international tourism remains stable, the share of inbound tourism has remained practically unchanged in recent years, with the majority $(78 \%)$ being tourists from the former USSR, primarily from Russia, Belarus and Moldova. Regarding other countries, most tourists, who visit Ukraine, are from Romania, Hungary, Slovakia and Poland.

The scale of tourist flows (Table 2) depends on the macroeconomic situation, real incomes of the population, availability of objects of tourist infrastructure and image of tourist objects.

Table 2

Distribution of tourist flows

\begin{tabular}{|c|c|c|c|c|}
\hline & \multirow{2}{*}{$\begin{array}{c}\text { Number of tourists } \\
\text { served by tour } \\
\text { operators and travel } \\
\text { agents, in total }\end{array}$} & $\begin{array}{c}\text { Including } \\
\text { (foreign) } \\
\text { tourists }\end{array}$ & $\begin{array}{c}\text { outbound } \\
\text { tourists }\end{array}$ & $\begin{array}{c}\text { domestic } \\
\text { tourists }\end{array}$ \\
\hline $\mathbf{2 0 1 0}$ & 2280757 & 335835 & 1295623 & 649299 \\
\hline $\mathbf{2 0 1 1}$ & 2199977 & 234271 & 1250068 & 715638 \\
\hline $\mathbf{2 0 1 2}$ & 3000696 & 270064 & 1956662 & 773970 \\
\hline $\mathbf{2 0 1 3}$ & 3454316 & 232311 & 2519390 & 702615 \\
\hline $\mathbf{2 0 1 4}$ & 2425089 & 17070 & 2085273 & 322746 \\
\hline $\mathbf{2 0 1 5}$ & 2019576 & 15159 & 1647390 & 357027 \\
\hline $\mathbf{2 0 1 6}$ & 2549606 & 35071 & 2060974 & 453561 \\
\hline $\mathbf{2 0 1 7}$ & 2806426 & 39605 & 2289854 & 476967 \\
\hline $\mathbf{2 0 1 8}$ & 4557447 & 75945 & 4024703 & 456799 \\
\hline
\end{tabular}

Thirdly, the underdevelopment of the national tourism infrastructure and the uneven distribution of the number of tourist entities across the regions of Ukraine adversely affect the income from the provision of tourist services (Figure 1, Figure 2).

Fourthly, Ukraine has all the prerequisites for the development of green tourism, which can be considered as a specific form of ancillary economic activity in rural areas, using the natural and cultural potential of the region. 
Features of the organization of rural green tourism of different countries are given in Table 3.

Table 3

The features of green agritourism organizations in different countries

\begin{tabular}{|c|l|}
\hline Country & \multicolumn{1}{|c|}{ The features of green tourism organizations } \\
\hline Italy & $\begin{array}{l}\text { agritourism business is closely linked to the resort, international } \\
\text { specialized gastronomic and tasting tourism }\end{array}$ \\
\hline Austria & $\begin{array}{l}\text { guest occupation in gathering herbs, cooking dairy products, } \\
\text { pasturing livestock, active mountain and eco tourism }\end{array}$ \\
\hline Finland & abandoned houses located on the banks of protected lakes and rivers \\
\hline Romania & $\begin{array}{l}\text { there is the National Association of Rural and Cultural Tourism, } \\
\text { specializing in ethnographic and gastronomic tourism }\end{array}$ \\
\hline Poland & $\begin{array}{l}\text { lacking a close connection with the country's traditions, only } \\
\text { accommodation and food are provided }\end{array}$ \\
\hline France & $\begin{array}{l}\text { seaside farms, horse farms, wine farms, ski chalets, agri-cottages, } \\
\text { castles, fishing houses }\end{array}$ \\
\hline Spain & $\begin{array}{l}\text { rural hotels open on the Canary and Balearic Islands, as well as in } \\
\text { converted monasteries and historic castles }\end{array}$ \\
\hline Denmark & $\begin{array}{l}\text { there is a National Association of Agritourism, specializing in } \\
\text { cycling tourism }\end{array}$ \\
\hline
\end{tabular}

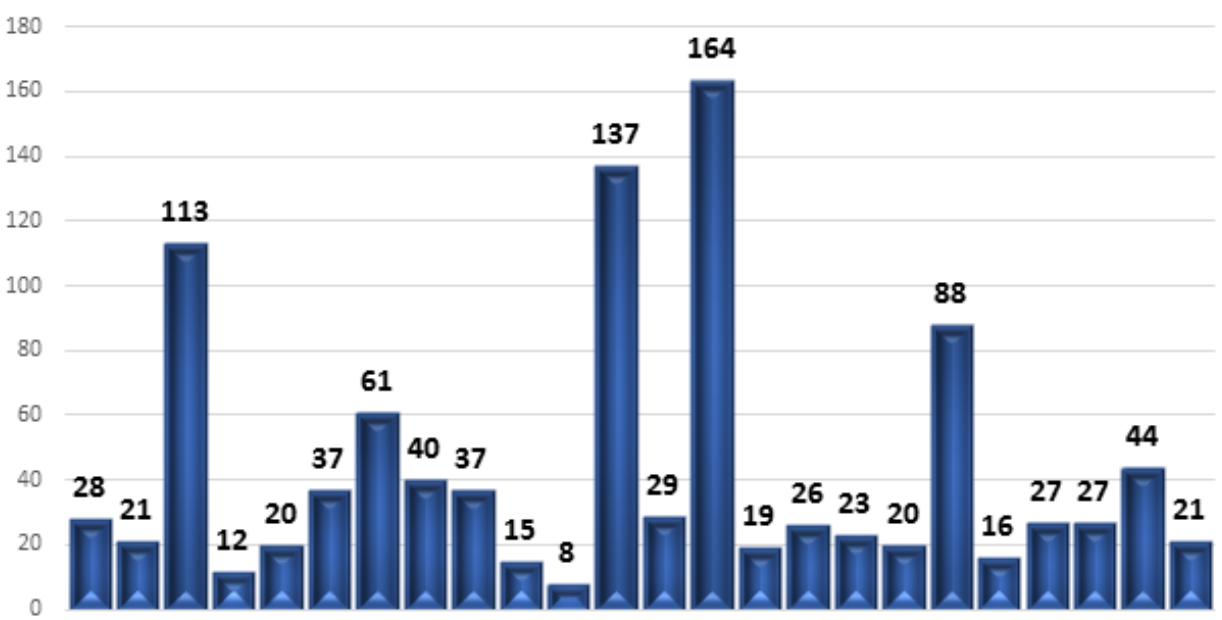

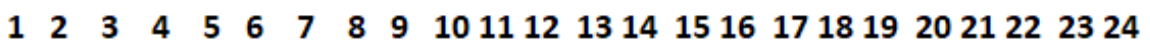

1. Vinnytsia Region

2. Volyn Region

3. Dnipropetrovsk Region

4. Donetsk Region

5. Zhytomyr Region

6. Zakarpattia Region

7. Zaporizhzhia Region

8. Ivano-Frankivsk

Region
9. Kyiv Region
10. Kirovohrad Region
11. Luhansk Region
12. Lviv Region
13. Mykolaiv Region
14. Odesa Region
15. Poltava Region
16. Rivne Region

17. Sumy Region

18. Ternopil Region

19. Kharkiv Region

20. Kherson Region

21. Khmelnytskyi Region

22. Cherkasy Region

23. Chernihiv Region

24. Chernivtsi Region

Figure 1. Distribution of a number of subjects of tourist activity by regions of Ukraine 


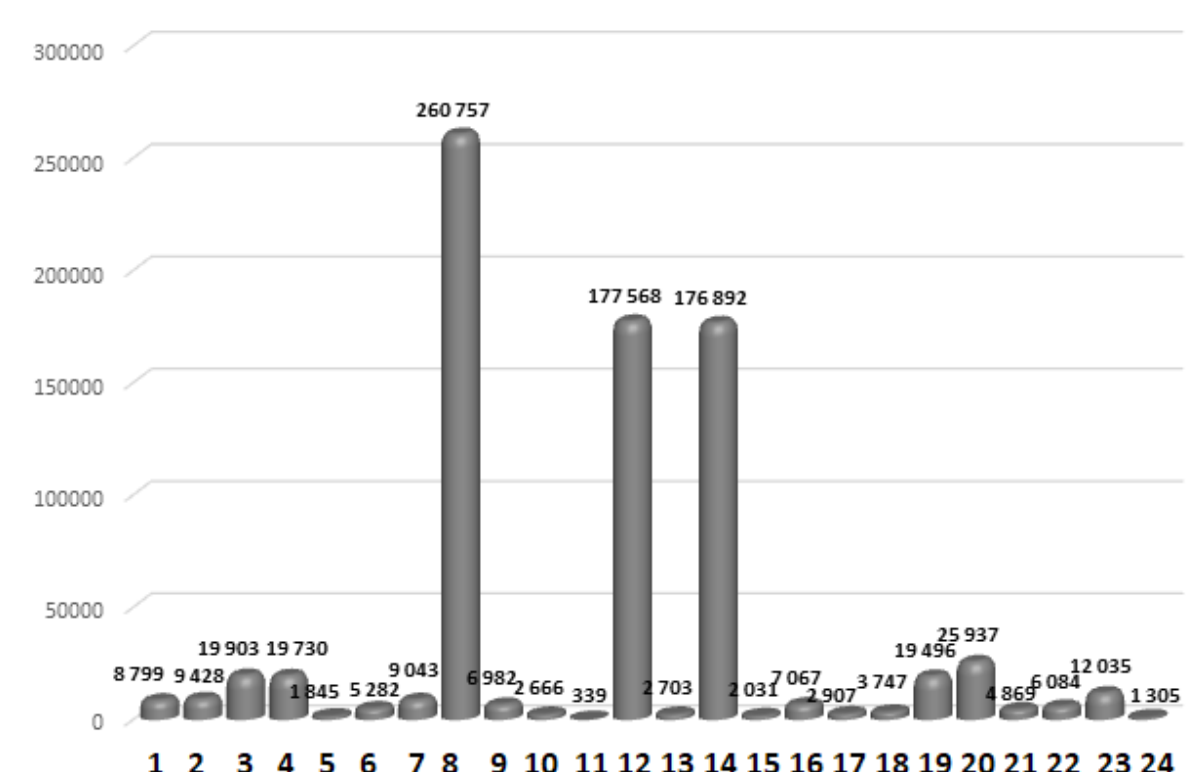

\section{Figure 2. Revenue from the provision of tourist services (excluding VAT, excise tax and similar mandatory payments) in the regional context for $\mathbf{2 0 1 8}$, in thousand UAH}

Territorial concentration of tourist enterprises reflects the territorial structure of demand: the highest number is in Kyiv, it is relatively high in Odesa, Kherson, Mykolaiv, Volyn, Zakarpattia, Ternopil, and the lowest is in Kirovohrad, Khmelnytskyi, Donetsk and Luhansk regions.

The area of developed and potential recreational areas in Ukraine is distributed according to the natural features of seven recreational regions: the Carpathian, the Transnistrian, the Crimean, the Black Sea, Dnieper, DonetskPryazovsk, Polissia.

The potential fund of protected, health and recreational areas is 12.1 million hectares, which is $20 \%$ of the area of Ukraine, which corresponds to the international indicators of rational conservation of natural and recreational resources. The one-time capacity of the landscapes of Ukraine, taking into account the permissible environmental standards, is over 40 million people.

These prerequisites demonstrate that Ukraine objectively has all the opportunities for intensive development of domestic and foreign tourism: features of geographical location and relief, favorable climate, rich natural, historical, cultural and tourist recreational potential. However, today in Ukraine, the development of this important area of the national economy is insufficient, although, according to experts, up to 4 billion USD can be brought annually to the state treasury only in the form of taxes.

Our country belongs to the group of countries with little impact of the tourism industry on the national economy, in the structure of domestic GDP the tourism industry occupies less than $2 \%$, and the effect of the industry is assessed by experts as extremely negative, especially due to tourism. With small volumes of consumption of tourist services, these processes are not critical, but a gradual increase in imports of tourist products (goods and 
services) without balancing export operations can lead to structural imbalances in the economy. Today, the direct contribution of the industry is about 1.3 billion USD, which is a significantly low figure for a country with a population of many millions.

At the present stage, Ukraine is far behind of many countries in the provision of tourist services, although in agriculture, green tourism, both in terms of volume and potential, the country has significant opportunities. Based on the vision of rural tourism in Ukraine, we identify its strengths and weaknesses, and single out opportunities and risks (SWOT analysis), which overall constitute a holistic concept of green tourism development in Ukraine (Table 4) [7].

Fifthly, today, the main problem is managing tourism as a cross-sectoral national economy at a regional level and bringing it into line with international standards. Until recently, the role of tourism in the socioeconomic development of the country and its regions has been underestimated in Ukraine. Increasing attention to regional aspects of economic development in this period has led to a significant expansion of theoretical studies in this area.

Over the last 10 years, tourism has become a driving force for socioeconomic development in many countries. In more than 100 countries, tourism contributes to a high level of employment, development of individual regions and is an important item of state budget revenues. We will give as an example some information about results of tourist activity in the Mykolaiv region (Figure 3). In 2019, there were 687 tourist entities in the Mykolaiv region (of which: 3 tour operators, 81 travel agents, 3 entities engaged in sightseeing activities), 102 collective facilities for 12620 places. In 2019, the local budget of the region has received 4340 million UAH tourist fee, which is $58 \%$ more than in 2018 ( 1833 million UAH).

The realization of creative events is supported by the following data: in the Mykolaiv region more than 14 annual festivals are held both in winter and in summer; during 2019, representatives of the Mykolaiv region took part in five exhibitions and fairs (Kyiv, Lviv and Minsk) and held presentations of tourist and recreational opportunities during 7 specialized tourist events in the cities of Kyiv, Odesa, Mykolaiv, Lviv, Ternopil, and Chernihiv.

The travel agency Leader-Tour introduces not only standard trips on interesting tourist routes for Mykolaiv residents, but also gives its tourists the opportunity to experience the economy of impressions. When developing authoring routes, employees of the travel company use creative approaches and try to fully uncover the tourist potential of the Mykolaiv region (thematic trips to the Mykolayiv region for the holiday of Ivan Kupala, youth festival «Mykolaiv loves St. Nicholas», information booklets «information in the pocket», one of the European countries, a tourist route (a boat trip on the river Pivdennyi Buh from Mykolaiv to Ochakiv) «Time runs faster - so do not hurry yet». 
SWOT-analysis of green agricultural tourism in Ukraine

\begin{tabular}{|c|c|}
\hline $\begin{array}{c}\text { Strengths (advantages) } \\
\end{array}$ & Weaknesses (disadvantages) \\
\hline $\begin{array}{l}\text { Geographical location } \\
\text { 1. Convenient geographical location. } \\
\text { 2. The number of rural settlements. } \\
\text { 3. Uniqueness of landscapes. }\end{array}$ & $\begin{array}{l}\text { 1. Weak development of international } \\
\text { routes. }\end{array}$ \\
\hline $\begin{array}{l}\text { Tourism potential } \\
\text { 1. Priority direction of industry development. } \\
\text { 2. Favorable economic and geographical } \\
\text { location on the map of Europe. } \\
\text { 3. International airports and a dense } \\
\text { network of routes. } \\
\text { 4. Powerful recreational opportunities. } \\
\text { 5. Rich historical and cultural heritage. } \\
\text { 6. Unique tourist objects, so-called «tourist } \\
\text { records». } \\
\text { 7. Ethnographic diversity, preserved } \\
\text { traditions, folk crafts, regional cuisine). } \\
\text { 8. Favorable conditions for the development } \\
\text { of ski tourism. } \\
\text { 9. Bases for training athletes, infrastructure } \\
\text { for cycling in mountainous areas. }\end{array}$ & $\begin{array}{l}\text { 1. Insufficient use of recreational resources. } \\
\text { 2. Insufficient interaction of small tourism } \\
\text { business owners and estates. } \\
\text { 3. Insufficient quality and range of tourist } \\
\text { services, lack of entertainment industry. } \\
4 \text {. Insufficient information on economic and } \\
\text { tax regulation of entrepreneurship in the } \\
\text { field of tourism. } \\
\text { 5. Service personnel in accommodation } \\
\text { establishments do not speak foreign } \\
\text { languages. } \\
\text { 6. Underdeveloped network of equipped } \\
\text { tourist routes, shelters, observation decks, } \\
\text { information stands near excursion objects. } \\
\text { 7. Insufficiently developed ecotourism on } \\
\text { the basis of nature reserves. }\end{array}$ \\
\hline $\begin{array}{l}\text { Social sphere } \\
\text { 1. Historical and cultural heritage. } \\
\text { 2. The presence of an original culture. } \\
\text { 3. High level of spirituality. } \\
\text { 4. Developed network of socio-cultural } \\
\text { facilities. } \\
\text { 5. A significant number of masters of folk art. } \\
\text { 6. Participation of gifted youth in socio- } \\
\text { cultural events. } \\
\text { 7. Honoring national heroes. } \\
\text { 8. Insignificant prevalence of prostitution, } \\
\text { alcoholism, AIDS. }\end{array}$ & $\begin{array}{l}\text { 1. Weak material and technical resources of } \\
\text { cultural institutions. } \\
\text { 2. Insufficient level of technical equipment } \\
\text { with modern machinery and equipment of } \\
\text { medical institutions, educational } \\
\text { institutions. } \\
\text { 3. Careless attitude to spiritual traditions. } \\
\text { 4. Low culture of rest. } \\
\text { 5. Low level of household culture. } \\
\text { 6. Lack of funds, insufficient budget } \\
\text { funding for education and health care. }\end{array}$ \\
\hline & \\
\hline $\begin{array}{l}\text { 1. Development of territories and solving } \\
\text { current problems of the tourism industry } \\
\text { through the implementation of tourism } \\
\text { projects with the involvement of } \\
\text { international technical assistance. } \\
\text { 2. Deepening of promotional and marketing } \\
\text { activities in tourism. } \\
\text { 3. Development and promotion of the } \\
\text { excursion product and creation of a } \\
\text { favorable environment for the activities of } \\
\text { tourist support specialists. } \\
\text { 4. Development of ski infrastructure, } \\
\text { creation of new ski complexes. } \\
\text { 5. Landscaping of recreational areas, tourist } \\
\text { routes, river banks, arrangement of places of } \\
\text { rest for tourists, observation decks, and } \\
\text { installation of indexes to tourist objects. } \\
\text { 6. Possibility of creation of regional clusters } \\
\text { (tourist, forest complex). } \\
\text { 7. Development of folk crafts. } \\
\text { 8. Development of resort and recreational areas. } \\
\text { 9. Development of green tourism. }\end{array}$ & $\begin{array}{l}\text { 1. Instability, change of legislative and } \\
\text { regulatory framework. } \\
\text { 2. The threat of loss of economic } \\
\text { independence due to the expansion of } \\
\text { capital (external and from other regions) } \\
\text { 3. The level of corruption. } \\
\text { 4. Deterioration of the demographic } \\
\text { situation. } \\
5 \text {. The presence of the shadow sector of the } \\
\text { economy. } \\
6 \text {. Reducing the solvency of consumers and } \\
\text { tourists. } \\
\text { 7. Deterioration of the investment climate. } \\
\text { 8. Competition of the tourism industry of } \\
\text { other countries. } \\
\text { 9. Insufficient funding from the social } \\
\text { sphere budget. } \\
\text { 10. Environmental problems associated with } \\
\text { environmental pollution by household } \\
\text { waste, wastewater. }\end{array}$ \\
\hline
\end{tabular}




\section{Tourist potential of the region}

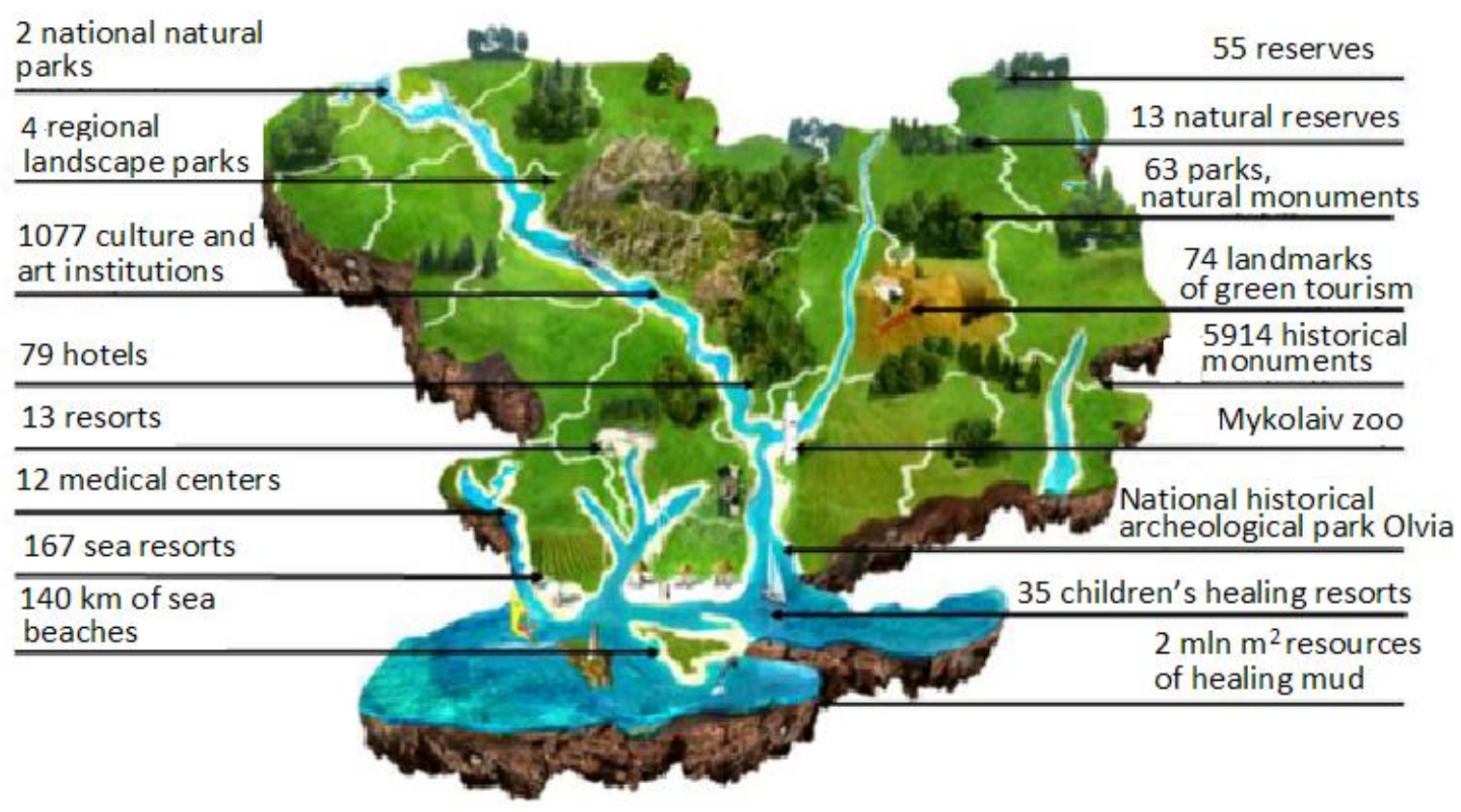

Figure 3. Figure of the tourist potential of the Mykolaiv region

The main components of recreational and health potential of the Black Sea coast, which are used by the tourist organizations of the Mykolaiv area, are the following:

- Koblevo recreation area, which has $7 \mathrm{~km}$ sandy beaches, 200 accommodation and catering facilities, more than 15 thousand places. There is a potential in developing youth and family recreation, organizing event and ecological tourism;

- Rybakivka recreation area where there is a large number of children's health facilities. The development of family and children's recreation is promising;

- Ochakiv-Black Sea recreation area, which has $34 \mathrm{~km}$ sandy beaches, 100 accommodation and catering facilities for 10 thousand places. There is a potential in developing children's and family recreation, organizing historical and cultural, yacht and sports tourism, creating tourist complexes and infrastructure.

- The regional landscape park «Tylihulskyi» is the protected object which includes the coast and adjacent waters of the Tylihul estuary with a total area of 8195.4 hectares. The park has great potential and conditions for organized tourism and recreation, research.

In the Mykolaiv region, there are 5914 immovable monuments where 4490 are monuments of archaeology, 1199 monuments of history, 67 monuments of monumental art, 145 monuments of architecture, 11 monuments of garden and park art, 1 monuments of landscape, 1 monuments of science and technology. Thirty monuments have the status of «national significance». There are 74 objects of rural (green) tourism in the region. 
Hence, tourism in Ukraine has a huge potential and all the prerequisites for development. Domestic travel companies should be interested in expanding the geography of routes in Ukraine. For this purpose, it is necessary to constantly study the possibilities of using all new tourist resources, which can attract tourists' attention, without dwelling on the main business cards of the Ukrainian tourism, such as Lviv, Odesa, and Kyiv.

In order for Ukraine to move to the stage of innovative society as soon as possible, it is necessary to introduce and develop creative processes in the service sectors more intensively. Creativity in developed countries is becoming a common practice and a major source of competitive advantage. Therefore, it becomes crucial to introduce creative management in the tourism sphere of Ukraine.

\section{Conclusions}

The conducted research made it possible to realize the set goals and fulfill all outlined tasks of the scientific work. As a result, we have reached the following conclusions. In the tourism industry, like no other, the phenomenon of synergy of production, entrepreneurial and creative processes, development of creative projects in demand by the society and testing them on the market are evident. Today, tourism is one of the leading powers in the development of the world economy. This process takes place in the following areas: the expansion of the sphere of influence of culture activates the interaction of creative workers with entrepreneurs; new ideas stimulate the development of creative developments and products, attracts business attention to the development of new territories and contributes to the establishment of creative activities that were not implemented previously (for example, industrial or landscape design).

The use of creative management in tourism is very relevant. The presence in the organization of creative management is an opportunity to solve production and economic problems not by competitive struggle, but by entering the enterprise to a new level of creation and supply of tourist services.

Ukraine is a country with a favorable geographical position, is located at the intersection of international transport highways, known for the hospitality and sincerity of its people, has every reason to develop one of the most profitable spheres of the economy today - tourism.

Tourism is one of the most profitable areas of the national economy, which from year to year steadily increases the volume of tourism products in Ukraine without significant investment and government subsidies. During the development of market mechanisms to stimulate and promote the evolvement of tourism, it is necessary to solve a number of following problems:

- to form the entertainment sector of the Ukrainian tourist industry, which is practically non-existent;

- to spread the practice of creating and functioning of such innovative types of entertainment establishments as theme parks, interactive children's museums with libraries, which will significantly contribute to strengthening the tourist potential of the country; 
- the most common type of cultural and leisure facilities in demand in Ukraine are museums. They have a strong resource potential, so it is necessary to raise the level of competitiveness in the museum market to overcome the conservatism and traditional organization of tourist services;

- to improve the material and technical base of the exhibition activity;

- to increase the number of hotels that meet international requirements;

- to reduce the number of outbound tourism and increase domestic flows, which will help reduce the outflow of foreign currency to the economies of other countries;

- to renew the reconstruction of historical and cultural sites, to disseminate information about the diversity of our natural resources and historical and cultural heritage;

- to increase the level of general tourist infrastructure.

Therefore, the tourism potential of our country is enormous, so it is necessary to develop it and to involve in the tourist activity in our country both Ukrainians and foreign tourists. The development of regional and green tourism will help to strengthen the state of the Ukrainian tourism as a whole.

\section{References:}

1. Derzhavna sluzhba statystyky Ukrainy [Elektronnyj resurs]. - Rezhym dostupu: http://vvv.ukrstat.gov.ua/

2. Jakovlev V.Ju. Osnovanija kul'turnyh i kreativnyh industrij kak javlenija sovremennogo obshhestva / V.Ju. Jakovlev [Elektronnij resurs]. - Rezhim dostupu: https://cyberleninka.ru/article/n/osnovaniya-kulturnyh-i-kreativnyh-industriy-kak-yavleniyasovremennogo-obschestva

3. Novichkov N.V. O nekotoryh aspektah razvitija turizma kak chasti kreativnoj jekonomiki i jekonomiki vpechatlenij / N.V. Novichkov [Elektronnij resurs]. - Rezhim dostupu: https://cyberleninka.ru/article/n/o-nekotoryh-aspektah-razvitiya-turizma-kak-chastikreativnoy-ekonomiki-i-ekonomiki-vpechatleniy

4. Lapochkina V.V. Osobennosti jekonomiki vpechatlenij v period kon\#jukturnyh izmenenij na primere rynka turizma / V.V. Lapochkina [Elektronnij resurs]. - Rezhim dostupu: https://cyberleninka.ru/article/n/osobennosti-ekonomiki-vpechatleniy-v-periodkonyunkturnyh-izmeneniy-na-primere-rynka-turizma-rossiyskiy-opyt

5. Kuz'min O.Ye. Sutnist' ta typolohiia kreatyvnykh kolektyviv na promyslovykh pidpryiemstvakh / O.Ye. Kuz'min, O.O. Horiachka [Elektronnyj resurs]. - Rezhym dostupu: http://archive.nbuv.gov.ua/portal/ natural/Vnulp/Menegment/2011_714/04.pdf

6. Pekar, V. Vvedenie v jekonomiku vpechatlenij / V. Pekar [Jelektronnyj resurs]: URL: http://www.management.com.ua/

7. Irtyscheva I.O. Orhanizatsiia turystychnykh klasteriv iak efektyvnyj zasib upravlinnia turystychnym biznesom / D.S. Vojt, I.O. Irtyscheva // Visnyk KhNAU im. V.V. Dokuchaieva. Seriia «Ekonomichni nauky». - 2016. - № 1. - S. 300-308.

8. Svidruk I.I. Kreativnij menedzhment Navchal'nij posibnik / I.I. Svidruk. - K.: Centr uchbovoï literaturi, 2012. - 224 s.

9. Agamirova, E.V., Lapochkina, V.V. Jekonomika vpechatlenij: tanec v parke // Sovremennye problemy servisa i turizma. - 2014. - № 2. - S. 50-59.

10. Yastrems'ka O.O. Suchasni svitovi tendentsii rozvytku turyzmu / O.O. Yastrems'ka. - Problemy ekonomiky. - 2013. - № 1. - S. 22-27.

11 World Tourism Organization UNWTO [Electronic resourse]. - Accessed mode: http://www2.unwto.org/ 